\title{
The Role of Symbol in Delivering the Theme of Conflict between Reality and Illusion in Tennessee Williams' A Streetcar Named Desire
}

\author{
Ahmadi Mosaabad Masoud (Corresponding author) \\ Assistant professor, English Department, Faculty of Arts, Gonbad Kavoos University \\ Gonbad Kavoos, Glostan province, Iran \\ Tel: 98-91-1376-1217Ｅ-mail: ahmadimousa@yahoo.com
}

\author{
Ahmad Gholi \\ Lecturer, English Department, Faculty of Arts, Gonbad Kavoos University \\ Gonbad Kavoos, Golestan province, Iran
}

Tel: 98-91-1771-5701Ｅ-mail: freehero3000@yahoo.com

Received: July 1, 2011

doi:10.5539/ells.v1n2p31

\author{
Accepted: July 26, 2011 \\ Published: December 1, 2011 \\ URL: http://dx.doi.org/10.5539/ells.v1n2p31
}

\begin{abstract}
Symbols for Williams not only are the pure language of drama but also a poetic device to add aesthetic dimension and say more without utilizing many words. It goes without saying that they maintain important position in the architecture of his plays particularly in his monumental work, Streetcar Named Desire. So far, various critics have analyzed the play from numerous approaches. However, they neglected to explore the relationship between the symbols and the themes in the play. Therefore, the current article attempts to show how central symbols in $A$ Streetcar Named Desire move ahead the theme of conflict between illusion and reality.
\end{abstract}

Keywords: Symbol, Theme, Illusion, Reality

\section{Introduction}

This article not only endeavors to delve into the theme of the conflict between reality and Illusion in $A$ Streetcar Named Desire but also makes effort to find how some specific symbols in the play push forward the theme in question. Therefore, the introduction of the article is divided into two parts. In the first part, the history of symbolist drama along with Williams's symbolism will be briefly discussed; in the next part, background information about the intended theme will be offered.

\subsection{Symbol}

Simply symbols refer to anything that represents another thing. It began to dawn in the latter part of Stone Age (Cirlot, 1989).Symbols are interconnected to all aspects of humans' life, "it is in and through symbols that man consciously or unconsciously, lives, works, and has beings" (Symons, 1908, pp. 1). Indeed, symbols are essential requisite for knowledge and communication,

Symbols represent man's innovative and associative power. They have occupied all disciplines of knowledge and are vital parts of human ideas, attitudes, feelings, and emotions. Over centuries they have become effective means of communication both in literary and non-literary fields. Symbols are thus the repositories of human knowledge, experience, and emotions. [In fact] they form the most formidable and interesting part of communication (Joodaki, 2007, pp. 1).

In a literary sense, "symbol is an especially evocative kind of image; that is, a word or phrase referring to a concrete object, scene, or action which also has some further significance associated with it" ( Baldick, pp. 251-52). Broadly speaking in the realm of literature, there are two types of symbols: public and private. The symbols which their symbolic significance, are determinate within a specific culture are called conventional while those which their symbolic meaning is created by the author himself are named private (Abrams, 2004). The quality which differentiates the private symbols from the public ones is the vitality and originality of the private symbols; that is to say, unlike hackneyed public symbols, they originate from the fertile imagination and personal experience of the author. 
From the time, the Catholic Church developed symbolism with introducing The Second Shepherd's Play in the Middle Ages (Rush, 2005), it has been playing very active role on stage. The Elizabethan drama witnessed the innovative and exhaustive utilization of symbols. Shakespeare was towering figure in taking advantage of symbols in his plays,

His highly evocative and creative handling of symbols enriched the previous explicit level of symbolism and made it deeply moving and suggestively wide-ranging. Shakespeare's distinctive and eloquent manipulation of the linguistic resources of English and his astounding flight of imagination imparted new dimension to the symbols in his plays (Joodaki, 2007, pp. 16).

In the second half of $19^{\text {th }}$ century when the realism and naturalism intellectually and ideologically went bankrupt due to their excessive emphasis on exteriority, science and positivism in favor of inner and spiritual world, the symbolist drama came to the existence. The main concern of symbolists is the ideal-mysterious-inner world which human kinds cannot feel it with their physical eyes; as a result, they want to capture the essence of the above-mentioned world through the symbols. Similarly, Maeterlinck beautifully illuminates the concern of symbolist playwrights,

The poet's [or symbolist playwrights'] task was to reveal the mysterious and invisible qualities of life, its grandeur and its misery, which have nothing to do with realism. If we stay on a realistic level, we remain ignorant of the eternal world, and therefore of the true meaning of existence and destiny, of life and death. The poet [or symbolist dramatist] must deal what is unseen, superhuman and infinite (cited in Joodaki, p. 19).

Therefore, for symbolist playwrights dialogue and external events, as Rush (2005) mentions, are functional as far as they help the playwrights enter to the spiritual and emotional world so as to convey the spirit of the inner world.

One of American playwrights who extensively used symbols in his plays is Tennessee Williams; for example, he "once said that without his symbols he would have never left the St. Louis shoe factory to which his father condemned him" (Kolin, 1998, xii) Nevertheless, he is not a strict symbolist dramatist like Maurice Maeterlinck. Symbols are central in the critical discourse of Williams plays (Kolin, 1998) inasmuch as he employs them for a variety of reasons,

A major function of Williams's symbols, then, is to form an emotional bridge with the audience, to create a drama so emotionally charged with concrete universals of archetypal images that their realization breaks down the psychological walls of our separate selves, making particular general, the strange familiar, and even grotesque recognizable as but another dimension of the human condition (Thompson, 2005, p. 89).

Due to the importance of symbols in Williams's plays, his critics and scholars have studies the symbols of his works either separately or in relation with character. In fact, they have not explored the relationship between the symbols and the themes in his plays. Therefore, the current study undertakes to indicate how symbols in particular central symbols in A Streetcar Named Desire deliver the theme of dilemma between reality and illusion.

\subsection{Theme of conflict between reality and illusion}

In his masterpiece, A Streetcar Named Desire, Williams features the theme of conflict between reality and illusion. Being equipped with this theme in the context of history will be helpful in firm grasping of the play in scrutiny. Abbott (1989) in his seminal book, The Vital Lie: Reality and Illusion in Modern Drama discusses the theme in question. Its summary goes like this: human beings want to live abundantly. But the formidable obstacle in their path to attain their goal is the external world; nevertheless, to live abundantly is not inaccessible. The yearning to have an abundant life will come true if there is a proper balance between joy and purpose inasmuch as the soul wants joy and purpose simultaneously. The soul can quench its thirst for joy and purpose through creating harmony between the Christian and pagan lifestyle. The Christian way of life satisfies the need to serve through self-sacrifice, duty, and commitment to service while the pagan lifestyle fulfills the craving for the joy of life through celebration, music, and dance. The significance of living abundantly lies in the fact it keeps the fear of death away and engenders the sense of peace and tranquility. The Roman Catholic Church was successful in bringing joy and dispelling the fear at the same time, but in the $16^{\text {th }}$ century the Reformation excluded the joy. If the Reformation deprived the people from the joy and shattered the delicate and ideal balance, Darwin, Marx, and Freud respectively dethroned God and explicitly denied his existence. Toppling God from his divine throne and excluding joy form the life of humans created an absurd world in which there is not individual identity, fixed meaning, and a sense of self. The duty of hero in this senseless world is creating meaning for himself. In other words, he must adopt a set of illusions to live in this absurd world. 
Eyvazi (2009) believes the conflict between reality and illusion stems from Williams's own experience and the campaign of the degrading realities of modern life against the sensitive and idealist souls,

Tennessee Williams is highly sensitive and receptive artist. The decisive and adverse influences on him during his tender age, the weakening of the ties between human beings, the deadening of the sentiments of and the gripping sense of crude realities give rise to the dilemma between illusion and reality... Williams like his master Lawrence believes that the industrial development brought in the machine age which terminated all validity of life, killed natural mode of life and dried sensitivity. The modern age dominated by professionalism, practical utility and self centeredness broke tender human bonds and precluded meaningful relationships. The sensitive and emotionally inclined individuals got crushed under heavy weight of practical demands and hard realities...in other words the harsh and hard reality conflict with inner sensitive world [illusion] (pp. 43).

To put it simply, when sensitive individuals encounter disgracing reality, they take on self devised illusion in their desperate attempt to survive in this absurd world. This is exactly what this article means by the dilemma between reality and illusion.

\section{Discussion}

In A Streetcar Named Desire, to convey theme of the dilemma between reality and illusion, Williams capitalizes on supporting and central symbols. Central symbols are the main focus of readers; they have different functions, "provide a tangible object for the readers' emotions... become the hub for meanings and associations" (cited in Kesauly and Hermansyah, 2004, pp. 64). The most important function of the central symbol is delivering the theme(s). Unlike central symbols, supporting symbols help the playwright to accentuate the central symbols. In the play in scrutiny, three characters: Stanley, Mitch, and Stanley fulfill the function of supporting symbols while paper lantern and bath function as central symbols.

\subsection{Supporting symbols}

In A Streetcar Named Desire, Williams creates three symbolic characters: Stanley, Mitch, and Blanche who serve as supporting symbols. The symbolic significance of these characters becomes evident through light which "is traditionally linked with knowledge and truth" (Ferber, 1999, pp. 112). Therefore, Stanley and Mitch's reliance on light to discover real Blanche establish them as the symbols of reality. While Blanche's a feeling of hatred towards light indicates that she is the representative of illusion.

Light for Stanley functions like a lie detector and reveals for him the truth which Blanche attempts to hide. By way of illustration, returning from work and greeting Blanche, Stanley goes directly to the closet and gets his whisky. To his amazement, he finds the bottle is empty. Then, "he holds the bottle to the light to observe its depletion" (pp. 28). Stanley surmises that it is Blanche who depleted his whisky though she claims that she rarely drinks whisky,

\section{[STANLEY]: Have a shot? \\ BLANCHE: No, I--rarely touch it.}

\section{STANLEY: Some people rarely touch it, but it touches them often (ibid.)}

With holding the bottle under light, Stanley conjectures about Blanche's double life: from one aspect she behaves like a sophisticated lady, from the other, she secretly empties Stanley's whisky.

For Mitch light is the emblematic of reality which Blanche wants to conceal from him. In scene nine, Mitch insists on seeing her under the direct light without the dimming effect of paper lantern, "I don't think I ever seen you in the light" (pp. 155); he also complains that she just goes outside with him in the evening instead of afternoon when there is enough to see her well, "You never want to go out till after six and then it's always some place that's not lighted much" (pp. 156). In the same scene, when he sees her under direct light, he finds out that she has lied to him about her age, "I knew you weren't sixteen" (pp. 157). Thus, Mitch's reliance on light and his intense inclination to see Blanche under the full light substantiates the claim that he is incarnation of reality.

Blanche's aversion of naked light proves that she is the symbol of illusion. Griffin (2005) remarks that "Blanche's light images are related to Allen" (pp. 92). Blanche escapes the strong light because it reminds her about her husband's early suicide. Moreover, Muller (2001) points out that Blanche abhors the light because it reveals her fading youth and beauty. There are three examples in play which vividly demonstrate her dislike for the strong light, and confirm the notion that she is representative of illusion. Firstly, in the stage direction of first scene, Williams reveals her feeling of hatred towards the intense light, "her delicate beauty must avoid a strong light. There is something about her uncertain manner, as ... that suggests a moth" (pp. 6). Secondly, in the first scene when Stella asks her to have a look at her, she refuses and says, "but don't you look at me, Stella, no, no, no, not ... turn that 
over-light off! Turn that off! I won't be looked at in this merciless glare!" (pp. 11). Thirdly, Blanche in the scene three requests Mitch to cover the light bulb with the Chinese lantern because she cannot tolerate it, "I can't stand a naked light bulb, any more than I can a rude remark or a vulgar action" (pp. 66).

\subsection{Central symbols}

\subsubsection{Paper lantern}

Williams conveys the theme of conflict between reality and illusion by taking advantage of two paper lantern as central symbols. According to Adler, "the lantern is ... the major' symbol of the play" (Kolin, 1998, pp. 62). This central reflects theme in question when Stanley and Mitch tears it off.

Firstly, Corrigan (2005) remarks that "the conflict between Blanche and Stanley is the externalization of the conflict that goes within Blanch between illusion and reality" (pp. 87); however, one can extend the scope of her claim and can say that their conflict is the externalization of illusion and reality in the play. Williams illustrates this conflict through Blanche's paper lantern. In the final scene when Stella, Eunice, nurse and doctor were preparing Blanche to take her away into the mental institution, Stanley separates himself from his friends playing cards. He then asks Blanche whether she has not forgotten one of her belongings. She coldly replies "I don't know you--I don't know you. I want to be--left alone--please!" (pp. 189). Her cold answer injures his pride in front of his friends watching him, thus, "He crosses to dressing table and seizes the paper lantern tearing it off the light bulb, and extends it toward her. She cries out as if the lantern was herself" (ibid.). As an embodiment of reality, Stanley likes to obliterate the trace of Blanche's illusion symbolized by her paper lantern. He knows that the existence of her paper at his home is a kind of challenge to his light-loving tendency. Thus, when Stanley rips her favorite paper lantern with which she identifies herself, he in fact symbolically confronts her world of illusion which is incongruous with his reality. And the fact that she cries over her torn paper lantern which neutralizes the cruel reality of her betraying past and passing beauty, is her last futile attempt to revolt and resist against reality represented by Stanley. Consequently, Williams conveys the theme of dilemma between reality and illusion by means of Blanche's paper lantern when Stanley tears it.

Secondly, when Mitch hears about her sordid past from Stanley, with his disheveled appearance he visits Blanche alone in Stanley's shabby apartment; he insists on seeing her face under direct light without the romantic and dimming effect of the paper lantern, but she refuses it and regards it as an insult. Filled with bitter anger, "[Mitch] tears the paper lantern off the light bulb. She utters a frightened gasp" (pp.156),

BLANCHE: What did you do that for?

MITCH: So I can take a look at you good and plain!

BLANCHE: Of course you don't really mean to be insulting!

MITCH: No, just realistic.

BLANCHE: I don't want realism. I want magic!

[Mitch laughs] (pp. 156).

Before Stanley tarnished Blanche's image with revealing her sordid past in Laurel where she led the life of prostitute, Mitch was under influence of Blanche's illusion and part of her romantic world. When he gets cognizant of her inglorious past, he comes under powerful influence of Stanley's reality and becomes the arch enemy of Blanche's illusion. Therefore, to express his bitter hatred to her illusion, he tears her off paper lantern which fortifies her illusion. In same vein, Griffin (2005) notes that "the light bulb and colored paper lantern covering it represent the contrast between the reality[Mitch and Stanley] that Blanche cannot face and magic she wishes to creates" (pp. 94). In addition, when Mitch endeavors to impose his reality by looking her under naked light and tearing her paper lantern off, she defends from her illusion and say, "Yes, yes, magic! I try to give that to people. I misrepresent things to them. I don't tell truth, I tell what ought to be truth. And if that is sinful, then let me be damned for it!--Don't turn the light on!" (pp. 157). In fact, Williams with taking advantage of paper lantern as a central symbol portrays the theme of the conflict between reality and illusion.

\subsubsection{Bath}

Another symbol which delivers the theme in question is bath. The role of bath become as a central symbol becomes evident when Blanche is in bathroom and Stanley tacitly persists in her leaving there immediately,

STANLEY: How soon is that going to be?

BLANCHE: Not so terribly long! Possess your soul in patience!

STANLEY: It's not my soul, it's my kidneys I'm worried about! (pp. 135). 
Cirlot (2001) regards that taking bath symbolizes purification and regeneration in the sense that it has calming effect on soul, "the symbolism of immersion in water derives from that of water itself, and signifies not only purification (a secondary symbolism taken from the general concept of water as a clear, cleansing liquid) but, more fundamentally, regeneration" (p. 230). In the play, Blanche frequently has a bath to forget her guilt over the suicide of her young-homosexual death, as well as to cleanse her mind of bitter hardship caused by Stanley in particular. In other words, for Blanche taking bath is illusion-motivated gesture to protect and cope with cold reality. Similarly, Foster (2007) states that Blanche uses bath for therapeutic use to calm and purify her soul, "her spiritual, therapeutic use of bathroom for cleansing that is symbolically regenerative" (p. 115). To give a clear example, Blanche in her conversation with her sister says that her hot bath refreshes her and gives her a new outlook; her speech lends support to the claim that she uses bath to escape brutal reality and take refuge in cozy arms of illusion. Unlike Blanche, Stanley, Foster notes, uses bath for mundane and practical thing like emptying her bowels thus for Stanley taking bath means to open his bowls and relieve her stomach without feeling any desired effect on his soul; that is why he says in scene seven, "It's not my soul, it's my kidneys I'm worried about!" (p. 23) when Blanche asks him to be patient, seeing him waiting her to come out of bathroom immediately. Foster (2007) believes the above repartee between Blanche and Stanley about bath, "represents the classical conflict between soul and body" (p. 115). However, their exchange also tellingly reflects the battle between the illusion and reality because the bath is a zone where illusion vies with reality and each other: Stanley (reality) wants to go there as soon as possible, but Blanche (illusion) does not like to leave the place. By incorporating bath symbolism, Williams beautifully pushes forward the theme of conflict between reality and illusion.

\section{Conclusion}

In Streetcar Named Desire, Williams artistically conveys the theme of the conflict between reality and illusion through two central symbols: paper lantern and bath. In the above-mentioned battle Blanche is symbol of illusion while Stanley and Mitch are emblems of reality. In the play, when Stanley and Mitch relentlessly tore her much beloved paper lantern which dims the intense light, artistically covers her wrinkles, and creates romantic atmosphere, they in fact destroy her illusions including the sense of superiority, gentility, and beauty. Finally, Blanche's bathing which is done for the purposes such as purification, regeneration, and the alleviation of her guilt-ridden soul, is motivated by her desire to create a fortress of illusion to fight and defend herself romantically against the unromantic world of Stanley and Mitch. But Stanley's bath is practical and closely ties him to the reality because he bathes to open his bowels not to refresh his soul; therefore, when Stanley insists Blanche to leave the bath apace while Blanche is not going to leave there, symbolically portrays the conflict between reality and illusion.

\section{References}

Abbot, Anthony. (1989). The Vital Lie: Reality and Illusion in Modern Drama. London: University of Alabama Press.

Abrams, M. H. (2005). A Glossary of Literary Terms. Boston: Thomson Wadsworth.

Baldick, Chris. (2001). Concise Oxford Dictionary of Literary Terms. New York: Oxford University Press.

Cirlot, J. E. (2001). A Dictinary of Symbols. (J. Sage, Trans.) London: Routledge.

Corrigan, Marry. (2005). On Illusion and Reality. In Harlod Bloom (Ed) Bloom's Guide: Tennessee Williams' A Streetcar Named Desire. The U.S.: Chelsea House Publishers. pp. 84-90

Eyvazi, Mojgan. (2009). Human Predicament in Selected Plays of Tennesseee Williams. Tehran: Kelke Simin Publishers.

Ferber, Michael. (1999). A Dictinary of Literary Symbols. Cambridge: Cambridge University Press.

Forster, Verna. (2007). Desire, Death, and Laghter: Tragicomic Dramaturgy in A Streetcar Named Desire. In Harlod Bloom (Ed), Bloom's Modern Critical Views: Tennessee Williams. New York: Infobase Publishing. pp. 111-121

Griffin, Alice. (2005). On the Symbols of Light and Water. In Harlod Bloom (Ed), Bloom's Guides: Tennessee Williams's A Streetcar Named Desire. The U.S.: Chelseahouse Publishers. pp. 92-94

Joodaki. Hossein. (2007). Symbolism in Absurd Drama. Pune: Diamend Publications.

Kesauly, Rosemary and Hermansyah, Harris. (2004). Symbols as a Means of Delivering the Theme in Nabokov's Lolita. Phenomena: Journal of Language and Literature, Vol. 8, No.1, pp. 61-69

Kolin, Philip. (1998). Tennessee Williams: a Guide to Research and Performance. Westport: Greenwood.

Muller, Krestin. (2001). [Online] Avialable: http://www.english-literature-uni-bayreuth.de/Williams/index.html (March 10, 2011) 
Rush, David. (2005). A Student Guide to Play Analysis. Carbondale: Souther Illinois University Press.

Symons, Authur. (1908). The Symbolist Movement in Literature. Edinburgh: Ballantyne Press.

Thompson, Judith. (2007). On Symbol, Myth, and Ritual. In Harlod Bloom (Ed). Bloom's Guides:Tennessee Williams' Glass Menagerie. New York: Infobase Publishing. pp. 89-94

Williams, Tennessee. (2000). A Streetcar Named Desire. Tehran: Rahnama. 